\title{
Farm Entrepreneurs' Intentions to Develop Pluriactive Business Activities in Finland
}

\section{Tarja Niemelä̈}

\begin{abstract}
We contribute to the entrepreneurial intentions literature by applying the theory of planned behaviour and resource-based views to the model of active entrepreneurs' intention to develop their pluriactive businesses. Using our 2012 survey data from farm firms in Finland, we address the limited focus on active entrepreneurs and their intentions to develop on-going income-generating, off-farm related business activities. We found that attitudinal proxy antecedents such as innovation, cooperation and growth for pluriactivity differ for active and non-active entrepreneurs and with respect to the entrepreneurs' age and production line and innovation behaviour.
\end{abstract}

Keywords: entrepreneurial intentions, off-farm related business, pluriactive entrepreneurs, theory of planned behaviour, resource-based view

\section{INTRODUCTION}

Substantial literature has addressed the concept of entrepreneurial intentions, viewing much of entrepreneurship as an intentional behaviour and the formation of a new venture creation process (Bird, 1988; Bird, 1992; Kolvereid, 1996; Krueger, Reilly \& Carsrud, 2000). However, some researchers have debated whether intentions can predict entrepreneurial behaviour (Douglas 2013; Douglas \& Shepherd, 2002). It has also been stressed who will develop the business activities (or not) in terms of entrepreneurial intentions (Shane, 2009). Little is known about the farm entrepreneurs' intentions to develop their existing business activities. We want to fill this gap by examining pluriactive farm entrepreneurs' intentions to develop their existing business activities.

Pluriactive farm entrepreneurs may give us an important insight into entrepreneurship research (Carter \& Ram, 2003) as portfolio entrepreneurs and owner-managers. By identifying pluriactive entrepreneurs with

1 Tarja Niemelä, Ph.D., School of Business and Economics, University of Jyväskylä, PO Box 35, FIN-40014, Jyväskylä, Finland, e-mail: tarja.niemela@jyu.fi. 
entrepreneurial intentions, and following the idea of Douglas (2013), governments can make use of public funding and private investments most efficiently by steering them toward people who start new businesses or develop their on-going pluriactive businesses because these businesses can impact rural economies, wellbeing and wealth creation for individuals (Alsos, Carter, Ljunggren \& Welter, 2011; Kinsella, Wilson, De Jong \& Rentig, 2000) and their families.

There exist only a few studies that include farm entrepreneur' intentions to develop their existing pluriactive, off-farm related business activities (Haugen \& Vik, 2008; Niemelä \& Häkkinen, 2014) Our study addresses this gap by investigating the intentions of active (income-generated) and non-active ("hobbyist") entrepreneurs to develop their off-farm related, pluriactive business activities focusing on the literature of entrepreneurial intentions (Davidsson \& Wiklund, 2001) and the theories of planned behaviour (Ajzen, 2011; Ajzen \& Fishbein, 1980), models of entrepreneurial events (Shapero \& Sokol, 1982), resource-based views (Barney, 1991; Wernefelt, 1984) and entrepreneurial orientation (Wiklund \& Shepherd, 2003).

Accordingly, our main research question is what differentiates active and non-active farm entrepreneurs in terms of pluriactivity and their intentions to develop their pluriactive business activities? More specifically, we want to examine whether the active pluriactive entrepreneurs who have the intention to develop their pluriactive business activities are younger, whether their educational level is higher and whether their attitudes towards pluriactivity are more innovative, cooperative and growth-oriented compared to nonactive pluriactive farm entrepreneurs.

By investing these issues, we contribute to the entrepreneurial intentions literature. We further develop the theories of entrepreneurial intentions by integrating personal characteristics, insofar as they help to explain entrepreneurs' behaviour and attitudes towards pluriactivity, with theories of resource-based views, insofar as they help to explain the firmlevel behaviour of pluriactive farm firms, into the model of intention to develop pluriactive business activities. Second, we demonstrate that different attitudinal antecedents can explain intention to develop pluriactive business activities. Third, we show that several usual suspects of thought to determine entrepreneurial intention appear to hold only for pluriactive farm firms and for active pluriactive entrepreneurs.

We begin with the theoretical background of our research. We then describe our sample and collection of primary survey data from 460 farms. After the methods section, we operationalize our constructs, present hypotheses for the empirical study and deliver the results of the empirical study. We conclude with a discussion of the key findings in light of previous 
literature and suggest recommendations for entrepreneurship educators, policy makers and future research.

\section{LITERATURE REVIEW}

\section{Focus on entrepreneurial intentions}

Prior studies indicate that intentions are the best predictor of any planned behaviour, including the creation of new ventures (Bagozzi, Baumgartner \& Yi, 1989; Bird, 1988; Krueger, 1993; Krueger et al., 2000; Schjoedt \& Shaver, 2004). In entrepreneurship research, some scholars have casted doubts on whether intentions predict actual entrepreneurial behaviour (Douglas \& Shepherd, 2002). Several intentions models in the field of entrepreneurship have been developed over the years, such as the theory of planned behaviour (Ajzen, 1991, 2011) and the earlier formulation of the theory of reasoned action by Ajzen \& Fishbein (1980), as well as the model of entrepreneurial event theory that gained support as an explanation of entrepreneurial behaviour (Shapero \& Sokol, 1982). These approaches can be traced back to the theory of social learning introduced by Bandura (1977).

The theory of planned behaviour (TPB) posits that beliefs about the three cognitive antecedents of intentions, i.e., attitude, control and norms, influence behaviour (Ajzen, 1991; Ajzen, 2011). Attitude is one's own evaluation of behaviour (whether favourable or unfavourable) in question. Perceived behavioural control reflects perceptions that behaviour is personally controllable. Subjective norms, in turn, refer to social pressure to either engage or not engage in a particular behaviour. The entrepreneurial event model explains intentions based on perceived desirability, perceived feasibility, and the propensity to act. Scholars in the field of entrepreneurial intentions (Krueger \& Brazeal, 1994; Krueger \& Carsrud, 1993; Linan \& Chen, 2009) have agreed that entrepreneurial intentions depend on perceived desirability (motivation to exploit) and perceived feasibility (means required to exploit) of an opportunity, assuming that opportunity has been recognized previously. The perceived feasibility has been usually measured by selfefficacy (Douglas, 2013; McGee, Peterson, Mueller \& Sequeira, 2009) and perceived desirability by the individual attitude to income, risk, and decisionmaking autonomy (Krueger et al., 2000; McGee et al., 2009). Some authors have argued that the opportunity identification process relates to self-efficacy (Bandura, 1977; Krueger \& Brazeal, 1994) because self-efficacy leads to increased initiative and persistence, increasing the likelihood of succeeding with the intended action. The TPB has also been applied in agricultural 
studies to analyse the adoption of a new technology (Lynne, Casey, Hodges \& Rahmani, 1995) and innovations (Borges, Folett \& Vanderson, 2015).

\section{Approaches to pluriactivity}

Pluriactivity has been referred to as a survival strategy for farm households that need to find a sufficient income to survive but also a wealth accumulation strategy facilitating further development of the income (Bowler, Clark, Crockett, Ilbery \& Shaw, 1996) for farming families, as remedies for insufficient farming income, as well as a source of growth (Grande, Madsen \& Borch, 2011). Considering pluriactivity from the resource-based view (Barney, 1991), the motivation to pluriactivity enhances rare, inimitable or otherwise valuable resources and capabilities that can provide sustainable competitive advantage for farmers (Alsos et al., 2011), innovative activities (Zhou, Yim \& Tse, 2005) and cooperation between firms (Niemelä, 2004). We may also see pluriactivity as a farmer's entrepreneurial orientation towards growth in terms of practices and decision-making styles (Wiklund \& Shepherd, 2003). Some scholars have found that pluriactivity is a way to enhance farmers' access to information, experience, and knowledge as well as various business-related ties, all of which result in improving the potential to grow farmers' businesses (Alsos et al., 2011). Whether farmers who expect low profits from the traditional farm business are more likely to diversify as a means of spreading the risk and the effect of farm resources on starting another business (McNally, 2001) have also been considered. We propose that pluriactivity can be viewed also as a strategic direction and exploitation of new-born knowledge but also as opportunities resulting in better performance in pluriactive business.

Considering pluriactivity from the opportunities perspective, previous experience such as knowledge and skills gathered has been identified to be linked to entrepreneurs' motivation to discover new business opportunities (Alsos et al., 2011; Grande, 2011a; Grande, 2011b). Thus, entrepreneurs learn from both their experiences and others; whether successes or failures (Gibb, 2000; Minniti \& Bygrave, 2001), their previous business experiences strengthen the ability to discover and exploit opportunities as well as run one's own business (Politis, 2005). It has been argued that farmers desire independence, self-esteem or personal identity together with the flexible employment as identified reasons to engage in more than one income generation activity (De Silva \& Kodithuwakku, 2011). We may propose that motivational factors influence farmers' decisions to be pluriactive. Thus, pluriactivity serves as a context for this study; we consider pluriactivity as a diversification between onand off-farm related businesses and their varying dependencies on agriculture. 


\section{RESEARCH METHODS}

\section{Sampling, data collection and procedures}

Our sample consists of 460 farms in Central Finland. We obtained the names and addresses of $\mathbf{3 4 3 5}$ farm firms from the Information Centre of the Ministry of Agriculture and Forestry IACS (Integrated Administration and Control System) support register of 2010. ${ }^{1}$ We collected the data through a questionnaire sent by e-mail as well as by surface mail to entrepreneurs, whose email addresses were out of order or not mentioned in the IACS register between the $15^{\text {th }}$ December, 2011 and the $10^{\text {th }}$ January, 2012. One reminder was sent to those respondents who did not respond to our first survey questionnaire.

Our questionnaire for all farms included questions on farmers' personal, family and farm data, transfers to descendants and the economic foundation of their farm. Furthermore, we directed questions to only those farms that have created new business activities other than traditional farming (i.e., secondary and ancillary business activities, incorporated business activities). We included questions concerning the nature of new business activities, various assessments concerning their attitudes towards pluriactive business activities, networking and co-operation relationships, vocational training, public sector support and advisory system as well as the nature of rural areas as business environments (Niemelä et al., 2005; Niemelä \& Häkkinen, 2014).

We consulted and tested the questionnaire on three farm firm entrepreneurs and four agribusiness experts in December 2011. Based on the feedback, we finalized the survey. The questionnaire was sent to all farms in Central Finland ( $\mathrm{N}=3435)$, of which 460 were returned, reflecting a $13.4 \%$ effective response rate. This response rate is moderately low but consistent with other studies focusing on farm firms in Central Finland (Niemelä, Heikkilä \& Meriläinen, 2005) and in Finland (Rantamäki-Lahtinen, 2009). An explanation for the generally low response rates when farm entrepreneurs are targeted is that entrepreneurs prefer to use their time effectively, avoiding non-useful paperwork, as the surveys might seem to them (Carter, 1998).

We excluded some of the respondents' data from the analyses because of incomplete or partially completed survey questionnaires. Non-responses $(n=2975)$ were analysed further: not answered $(n=2909)$, of which: incomplete survey $(n=30)$, refused to answer $(n=6)$, and other reasons $(n=30)$. In the category of other reasons $(n=30)$, there were diverse explanations for nonresponses: 1 ) we are not actively farming anything ( $n=15), 2$ ) farm owner or farm hostess has retired $(n=5), 3$ ) farm firm has sold or its facilities (i.e., 
fields, machines, production, buildings) have been rented to other farms or otherwise $(n=6)$, and other $(n=4)$ reasons.

To test our hypotheses, we limited our sample to those farm firms, which were identified as pluriactive farm businesses $(n=189)$ out of a total of 460 farms. These farm businesses reported having new business activities that are diversified from traditional farming and core production and incorporated as businesses on their own. We employed a broad conceptualization of pluriactivity ${ }^{2}$ that branches out beyond traditional agriculture and forestry, which is the case of many Finnish farms. The final sample of 189 pluriactive farm firms consists of 124 family firms and 48 non-family farm firms ( $N=172$ ) and farms that were over 100 years old (established since 1880). Thus, the final sample comprises 143 responses on pluriactive farm firms, of which 108 firms indicated active and 35 firms' non-active pluriactive businesses. Based on this definition of pluriactive farms, the effective response rate was $31 \%$ (143 retained surveys out of 460 ).

Because we are interested in active entrepreneurs' intentions to develop their pluriactive business operations and we have divided pluriactive farm firms into active and non-active ones, we are convinced that the intention approach is a useful research strategy in our case (Orser, Hogarth-Scott \& Wright, 1998). We describe our data in more detail in the analyses and results section.

\section{Measures}

To capture the theoretical constructs and to examine the entrepreneurial intention of pluriactive farm entrepreneurs, we relied on self-reports and single tailor-made items that we developed in our earlier studies when investigating farm firms and farm firms' pluriactivity (Niemelä et al., 2005). Although the previous research in entrepreneurship yielded support for the reliability and validity of the self-reported measures (Lechner, Dowling \& Welpe, 2006), we are confident that our approach is valid because we have addressed concrete attributes that can be measured using single items. Our data were collected (Appendix A) on variable scales (scale, continuous) that have restricted our choices for analysis methods. We then used variable specific and logistic regression analyses as research methods because they allowed us to use nominal scale variables. We used proxies as linkages between the constructs and measures to test our hypotheses.

We were interested in the possible differences within active and nonactive pluriactive farm firms. In general, we set up the following hypotheses:

2 Prior research has defined pluriactivity as a concept that can be considered both as a source of livelihood of farm households (Kinsella et al., 2000) as well as a source of growth (Grande et al., 2011). 
(H1) entrepreneurs' intention to develop pluriactive business may mostly be explained by entrepreneurs' attitudes towards pluriactivity, $(\mathrm{H} 2)$ active pluriactive entrepreneurs with intention to develop pluriactive business activities are younger, and their educational level is higher (H3). Moreover, other more detailed but very tentative hypotheses are possible about personal and firm characteristics and intention to develop pluriactive business activities despite quite conflicting prior results concerning entrepreneurial intentions.

\section{Personal characteristics}

In general, demographic variables such as age, gender, and entrepreneur's prior education have been shown to affect entrepreneurial intentions in previous studies on entrepreneurship (Shane, 2003), as individual characteristics of the owner (Markantoni, Strijker \& Koster, 2013). We included entrepreneurs' age because it (continuous) has been associated with impacting the entrepreneurial process and outcomes related to firm development (Shane, 2003) and the extent and type of pluriactivity (Carter, 1998). We also included gender because it was considered an antecedent of entrepreneurial behaviour (Hill, 2000). Some authors have found that gender is not a key predictor of growth (Storey, 1994) and that men were significantly more likely than women to expand their businesses (Rosa, Carter \& Hamilton, 1996). Education, in turn, is one of the most frequently examined components of human capital (Ucbasaran et al., 2009). Some authors have found a positive relationship between education and growth (Wiklund \& Shepherd, 2005); however, other authors have failed to find significant influence of education on growth (Barkham, 1994). Thus, we may suppose that entrepreneurial intentions to develop pluriactive business are dependent on the entrepreneurs' age, educational level and gender.

\section{Firm characteristics}

The characteristics of small firms influence the development of pluriactive business activities as well as growth. Factors such as the size of the firm (e.g., number of employees), type of ownership, sources of capital, collaboration and the availability of land and space collectively comprise a set of predictors that are crucial to farm firms' success (Atterton \& Affeleck, 2010). It is also clear that larger firms, because of their access to resources and services, are expected to grow more than smaller firms (Wiklund \& Shepherd, 2003). Thus, we may suppose that the intention to develop pluriactive business is influenced by the size of the firm. To capture the farm's location, representing the regions in which the pluriactive farm businesses mostly act and are 
sited, we accounted for potential differences in rural areas per $\mathrm{se}^{3}$ and the entrepreneurial environment, which may influence the entrepreneurial activities of small businesses (Busenitz, West, Shepherd, Nelson, Chandler \& Zacharakis, 2003).

Prior studies have revealed that rural firms can respond actively to unfavourable environments (North \& Smallbone, 1996) such as small-scale markets, limited numbers of customers and underdeveloped infrastructure, by using their rural qualities such as land and space (Markantoni et al., 2013). Moreover, business opportunities are more numerous in urban locations, and urban areas may also provide ease of access to customers and necessary resources (Rotefoss \& Kolvereid, 2005). Given the focus on firms' locations in rural areas, urban centres and their direct surroundings, we may suppose that entrepreneurs' intentions to develop pluriactive business activities are influenced by the location of the pluriactive farm firm business.

\section{Entrepreneurs' intentions}

As Ajzen and Fishbein (1980) stated, intentions directly impact entrepreneurial behaviour that results from the personal attitudes towards specific behaviour and the social pressure to engage in certain types of behaviour. Accordingly, we have used attitudinal proxies such as innovation, cooperation and growth for measuring entrepreneurs' intention to develop their pluriactive business activities.

Innovativeness can be characterized on both firm and individual levels and facilitate explorative and exploitative innovations. Prior studies have shown that innovativeness is accompanied by both creativity and commitment to new ideas and progress, but at the same time also generates new ideas and facilitates the development and implementation of new inventions and products (Lumpkin \& Dess, 2005). Furthermore, innovativeness embodies the capability to realize any type of new opportunity and contributes to improving and refreshing the presence of the firm in existing markets and businesses.

Cooperation can be characterized by entrepreneurs' capability to accumulate resources and construct new favourable configurations of resource dependencies and learn from these interactions. Entrepreneurs use their evolving network relationships to meet their demands as their business needs new opportunities for growth or development (Granovetter, 1973; Ozcan \& Eisenhardt, 2009). Entrepreneurs' human capital, such as

\footnotetext{
3 Finland is one of the most rural countries within the OECD (http://www.oecd.org/finland/oecdruralpolicyreviewsfinland. htmrural). Typical rural areas have a low population density and small settlements. Agricultural areas are commonly rural, though so are others such as forests. Different countries have varying definitions of "rural" for statistical and administrative purposes, as does Finland.
} 
learning, have been related to entrepreneurial success and the successful development of their ventures (Davidsson \& Honig, 2003) and joint ventures (Niemelä, 2004). From the perspective of entrepreneurial learning, entrepreneurs, especially those in small owner-managed businesses, learn by means of experimentation from other entrepreneurs, from customer feedback, by adapting and copying, by solving problems and by grasping different opportunities (Gibb, 2000; Sullivan, 2000).

Growth can be characterized by both internal factors such as entrepreneurs' age, skills and experience, and external factors such as the age and size of the firm, which are related to growth of the firm (Storey, 1994). Wiklund and Shepherd (2003) found that non-economic motives are more important in explaining growth than the opportunity of individual economic gain and loss. Other studies have shown a positive relationship between growth motivations and business growth (Bellu \& Sherman, 1995; Kolvereid \& Bullvåg, 1996; Orser et al., 1998). Thus, we may suppose that entrepreneurs' intention to develop pluriactive business activities is dependent on the entrepreneurs' attitude towards, innovation, cooperation and growth.

Next, we will describe the measures used in this study. Because of the challenges of our empirical data collection in our research setting, we have collected the empirical data also for the purposes of practice (rural policy makers and enterprise development organizations): Accordingly, we chose to collect data on independent and dependent variables in the same survey. We only controlled the variable of pluriactive farm firms. Considering the combat common method variance as suggested by Chang, van Witteloostuing and Eden (2010), we used different scale types as described in the measurement scale items (Appendix A). We have used entrepreneurs' attitude towards pluriactive farm businesses, such as innovation, cooperation and growth, as a proxy for assessing their intention to develop their pluriactive business activities. To capture the attitude towards pluriactive businesses, our questionnaire consists of items on a 5-point Likert-type scale ranging from $5=$ extremely well to $1=$ not well.

Innovation was assessed using sample items: "In our field of industry other entrepreneurs often seek to learn in their own operations from us" ( $n=169)$, "We constantly seek new ideas and opportunities to develop our business" ( $n=169)$, and "We have often noticed to be the first experimenter in our field" ( $n=169)$. The reliability statistic (Cronbach's alpha) for this scale suggests that the scale is reliable at $\alpha=.759$ (Nunnally, 1978). Cooperation was assessed using sample items: "We are often the initiator of the cooperation and networking" $(n=168)$, "We are actively seeking more cooperation partners" ( $n=168)$ and "We are constantly seeking more and more cooperation possibilities with our existing co-partners" $(n=168)$. The reliability statistic 
(Cronbach's alpha) for this scale suggests that the scale is reliable at $\alpha=.841$ (Nunnally, 1978). Finally, Growth was assessed using sample items: "We consider growth as the pivotal target in our business $(n=169)$ and "Growth and profitability go hand in hand" ( $n=169)$. The reliability statistic (Cronbach's alpha) for this scale suggests that the scale is reliable at $\alpha=.750$ (Nunnally, 1978). Pluriactive farm firm was operationalized using a dummy variable that was coded as 0 if a firm is a non-pluriactive farm, 1 if a firm is pluriactive, reflecting if a farm firm focuses mainly on their primary production (e.g., milk or grain production), on ancillary or supplementary business activities, or on incorporated business activities beyond traditional farming. Further, Active pluriactive farm firm was operationalized by a dummy variable coded as 1 if a firm is an active pluriactive firm. We used two items such as "Primary and most important source of income" and "Provides extra income but is not related to traditional farming" reflecting the economic significance of pluriactive business activities, i.e., respondents' pluriactive business activities involve income generation and motivation to develop pluriactive business activities. Non-active pluriactive farm firm was operationalized by a dummy variable coded as 0 if a firm is a non-active pluriactive farm firm. We used items such as "Mainly a hobby" and "Provides extra income but is a natural supplement for basic agriculture" reflecting that entrepreneurs who refer to their pluriactive business as a hobby implied that the motivation is not economic reward per se (hobby) or their main source of income but is instead related to a lifestyle need and a need for supplementary income. Farm's size (continuous) was included as a variable to measure resources as the area of cultivated fields and forest (we asked entrepreneurs to estimate the area of cultivated fields and forest in hectares) reflecting the resources and opportunities for the development of the pluriactive business activities. The entrepreneurs' age (continuous) and education level as well as gender were measured as independent variables in the model because they might impact on entrepreneurs' intention to develop pluriactive farm firm businesses. Entrepreneurs' age was coded as follows: 1=50 years old, $2=51$ to 64 years old, $3=$ over 65 years and above. Education was coded as $1=$ lower education (includes middle school and elementary school degrees, vocational school degree, vocational courses) $0=$ higher education (includes high school, polytechnic and university level degrees, advanced training). Gender was coded as 1= female, 2=male.

\section{ANALYSIS/RESULT}

Our study aimed to answer the following questions: First, what factors separate the pluriactive and non-pluriactive farm firms regarding their 
entrepreneurship and its prevailing and future domains? Second, what differences are there between the active and non-active pluriactive farm entrepreneurs classified according to their intention to develop pluriactive business operations? Before proceeding to testing our hypotheses, we examined the characteristics of our scale variables.

\section{Which factors separate pluriactive and non-pluriactive farm firms?}

At the first phase of our study, we wanted to get a more holistic view on all farm firms $(\mathrm{N}=448)$ to find out what differences there were between pluriactive farms and non-pluriactive farms regarding their farm business activities. Furthermore, we wanted to test which factors influence whether a business is pluriactive or not.

Our full sample $(\mathrm{N}=460)$ showed us that $50.5 \%$ of the pluriactive farms were located in urban centres and their direct surroundings, whereas $61.5 \%$ of the non-pluriactive farms are located in rural areas. In turn, $44.4 \%$ of the pluriactive farm firm entrepreneurs were men and $29.3 \%$ were women. Of the entrepreneurs under 50 years old, $48.6 \%$ had pluriactive farm business activities, whereas $43.2 \%$ of the entrepreneurs between 51 and 64 years old had pluriactive farm business activities. In turn, only $24.8 \%$ of the entrepreneurs over 65 years old had a pluriactive farm business. Only $28.8 \%$ of the entrepreneurs with a lower level of education had a pluriactive business, whereas $45 \%$ of the entrepreneurs with higher level of education had a pluriactive farm business. In addition, $44.1 \%$ of the grain as a primary production line producers had a pluriactive business activity, and $40.1 \%$ of non-grain as a primary production line producers had a pluriactive business activity. Moreover, $31.1 \%$ of the milk producers had a pluriactive business activity, and $43.8 \%$ of non-milk producers had a pluriactive business activity.

The results of our full sample indicated that the gender of the entrepreneur $\left(\chi^{2}(2, N=446)=6.782, p<0.009\right)$ and entrepreneurs' age had a significant influence on whether a farm firm is pluriactive or non-pluriactive $\left(\chi^{2}(2, N=448)=15.32, p<0.000\right)$. The older entrepreneurs have a smaller proportion of pluriactive entrepreneurs. Additionally, the entrepreneurs' level of education has a significant influence on whether a farm firm is pluriactive or non-pluriactive $\left(\chi^{2}(1, N=458)=9.04, p<0.003\right.$.) Similarly, the results of the firm characteristics of the pluriactive farm firms indicated that grain production as a primary production line seem not to influence whether the farm firm has a pluriactive business or not $\left(\chi^{2}(1, N=444)=0.68, p<0.429\right)$. However, milk production as a primary production line seems to some extent to have influence on whether the farm firm has a pluriactive business or not $\left(\chi^{2}(1, N=444)=4.094, p<0.052\right)$. The location of the farm firm $\left(\chi^{2}(1\right.$, 
$\mathrm{N}=448)=4.562, \mathrm{p}<0.05$ ) has a significant influence on whether a farm firm is pluriactive or non-pluriactive.

Table 1 reports the means, standard deviations and Pearson's correlation coefficients between every pair of variables for the full sample $(\mathrm{N}=460)$.

Table 1. Means, standard deviations, correlations for the full sample $(\mathrm{N}=460)$

\begin{tabular}{lllllllllll}
\hline Correlations & $\mathbf{N}$ & Mean & SD & $\mathbf{1}$ & $\mathbf{2}$ & $\mathbf{3}$ & $\mathbf{4}$ & $\mathbf{5}$ & $\mathbf{6}$ & $\mathbf{7}$ \\
\hline $\begin{array}{l}\text { 1. Entrepreneur's } \\
\text { age }\end{array}$ & 448 & 1.91 & .74 & 1 & & & & & & \\
2. Location & 448 & 1.78 & .41 & -.070 & 1 & & & & & \\
3. Education & 458 & .76 & .43 & $-.348^{* *}$ & -.079 & 1 & & & & \\
4. Grain & 433 & .38 & .49 & -.027 & .064 & .018 & 1 & & & \\
5. Milk & 444 & .17 & .37 & $-.103^{*}$ & .015 & .039 & $-.315^{* *}$ & 1 & & \\
6. Gender & 430 & 1.79 & .41 & -.091 & -.009 & -.066 & $.095^{*}$ & -.057 & 1 & \\
7. Farm size & 437 & 124,27 & 168,21 & $-.188^{* *}$ & -.015 & $.163 * *$ & -.023 & .040 & .031 & 1 \\
\hline
\end{tabular}

$* * p<.01 ; *<.05$; (two-tailed), Pearson's $(\tau)$ correlation coefficients

To sum up, for the six independent variables, the largest coefficients between entrepreneur's age and education were $-0.348(p<0.01)$, which is moderately high, followed by $-0.315(p<0.01)$, the coefficient between milk as a primary production and grain as the production line. Only location does not significantly correlate with other variables. However, other variables were significantly correlated and were in line with the $\chi^{2}$ test results.

Regarding the differences between pluriactive and non-pluriactive farm firms, we found that five factors, namely age, gender, education, location of farm firm, and milk production as the primary production line, seemed to determine whether a farm firm is pluriactive or non-pluriactive. We also found that the entrepreneurs' age and education have a significant and high negative correlation, showing that older entrepreneurs have a lower level of education. Additionally, milk production and grain production have a negative correlation, which may show us that those farmers who are focusing on milk production (as their primary production line) are not grain producers (as their primary production line). We conclude that no single indicator of pluriactivity is reliable or sufficient; rather, we believe here that there are multiple factors and outcomes that have influenced the entrepreneurial process towards pluriactivity. 


\section{Which factors separate active and non-active pluriactive business activities?}

At the second phase of our analysis, we wanted to get a deeper understanding of the pluriactive farm firms ( $\mathrm{N}=189)$ and to find out what differences there are between the active and non-active farm firms regarding their pluriactive business activities. Furthermore, we want to test which factors influence whether the pluriactive business is an active or non-active business for entrepreneurs.

Our active and non-active pluriactive farm firms sample showed that $25.2 \%$ of the active pluriactive farms are located in urban centres and their direct surroundings, whereas $74.8 \%$ of the active pluriactive farms are located in rural areas. In turn, among the active pluriactive entrepreneurs, $84.7 \%$ were men and $15.3 \%$ were women. Among the active entrepreneurs, $16.3 \%$ had a lower level of education, and $83.7 \%$ of the active entrepreneurs had a higher level of education. Among the active entrepreneurs, $39.3 \%$ were under 50 years old, whereas $51.9 \%$ were between 51 and 64 years old. In turn, $8.9 \%$ of the active entrepreneurs were over 65 whereas $29.8 \%$ of the non-active entrepreneurs were over 65 years old. Furthermore, $56.8 \%$ of the active pluriactive farms are non-grain as primary production producers, and $43.2 \%$ of the active pluriactive farms are grain producers. In addition, $90.6 \%$ of the active farms are non-milk as primary production producers, and $9.4 \%$ of the active pluriactive farms are milk producers. Finally, $72.5 \%$ of the active farms are family firms and $29.3 \%$ are not family firms.

Regarding the differences between active and non-active pluriactive farm firms, we found that entrepreneur's age and milk production as a primary production line are the only factors that determine if the pluriactive business is active or non-active. However, farm size seemed not to influence whether the pluriactive business is active or non-active. One explanation can be that the existing premises for pluriactive business activities do not influence pluriactivity, although in small business contexts firms often use their existing resources (Storey, 1994; McNally, 2001). Table 2 reports the means, standard deviations, reliabilities and correlations for every pair of variables.

We found a strong connection between pluriactive entrepreneurs' innovativeness and cooperativeness, and cooperativeness and growth. Our findings may indicate that pluriactive entrepreneurs who are likely innovators are also cooperation-oriented, and entrepreneurs who are likely cooperation-oriented are also growth-oriented. Our findings concerning the innovation, cooperation and growth may refer to separate but correlated variables of attitudes towards pluriactivity, which are also predictors of the outcomes of the entrepreneurs' intention-behaviour. The Cronbach's alphas and reliabilities of all constructs exceeded the recommended threshold level 
of 0.70 , suggesting satisfactory reliability for the innovation, cooperation and growth variables (Nunnally, 1978). We also examined the inter-item correlations between items of innovation, cooperation and growth to ensure discriminant validity and to control for common method biases. After the chi-square and correlation tests, we conducted a sophisticated and robust multivariate analysis. By using multivariate analysis we examined more accurately if there were differences in the average of the measured variables such as farm size as well as innovation, cooperation and growth between active and non-active pluriactive farm entrepreneurs.

Table 2. Means, standard deviations, correlations for the variables for the pluriactive farm firms sample $(\mathrm{N}=189)$

\begin{tabular}{llllllllll}
\hline Correlations & $\mathbf{N}$ & Mean & SD & $\mathbf{1}$ & $\mathbf{2}$ & $\mathbf{3}$ & $\mathbf{4}$ & $\mathbf{5}$ & $\mathbf{6}$ \\
\hline 1. Innovation & 192 & 3.02 & 1.06 & 1 & $(.76)$ & & & & \\
2. Cooperation & 187 & 2.87 & 1.07 & $.698^{* *}$ & 1 & $(.84)$ & & & \\
3. Growth & 186 & 3.17 & 1.06 & $.356^{* *}$ & $.351^{* *}$ & 1 & $(.75)$ & & \\
4. Gender & 185 & 1.85 & 0.36 & $.221^{* *}$ & $.165^{*}$ & -.037 & 1 & & \\
$\begin{array}{l}\text { 5. Education } \\
\begin{array}{l}\text { 6. Entrepreneur's } \\
\text { age }\end{array}\end{array}$ & 191 & 0.83 & 0.38 & .010 & .060 & .017 & -.066 & 1 & \\
\hline
\end{tabular}

${ }^{* *} p<.01 ; * p<.05$; (two-tailed)

Pearson's $(\tau)$ correlation coefficients:

Note: Scale Reliabilities (Cronbach's alpha) are on the diagonal; in parentheses; bolded)

Table 3 reports means, standard deviation, mean squares, F-values, significance, Eta-squared in active (income generated) and hobbyist (nonactive) farm entrepreneurs. We found a statistically significant difference in innovation attitude between the active and non-active entrepreneurs, i.e., active entrepreneurs were more innovative than non-active entrepreneurs. Accordingly, the entrepreneurs' innovation attitude towards pluriactive business activities explained $4.3 \%$ of the variance of the innovation attitude. Entrepreneurs, i.e., active entrepreneurs, have a more positive attitude towards cooperation. The entrepreneurs' attitude towards pluriactive business activities explained $5.4 \%$ of the variance of the cooperation attitude. We found also a statistically significant difference in cooperation attitude between active and non-active entrepreneurs. Similarly, we found a statistically significant difference in the attitude towards growth between active and non-active entrepreneurs. Active entrepreneurs have a more positive attitude towards growth. The entrepreneurs' attitude towards pluriactive business activities explained $5.4 \%$ of the variance of the growth 
attitude. To sum up our findings regarding the differences between active and non-active farm entrepreneurs, we found that active pluriactive farm entrepreneurs seemed to be more innovative, cooperative and growthoriented than non-active pluriactive entrepreneurs.

Table 3. Means, Standard Deviations (SD), Means Squares, F-values, Significance and Eta Squared in Active-Oriented and Hobby-Oriented Pluriactive Farm Entrepreneurs ( $\mathrm{N}=169)$

\begin{tabular}{|c|c|c|c|c|c|c|c|}
\hline & $\mathbf{N}$ & Means & SD & $\begin{array}{l}\text { Mean square } \\
\text { between groups }\end{array}$ & F-value & Sig. & Eta2 \\
\hline Farm Size & & & & 66040.14 & 1,14 & & \\
\hline Hobby & 45 & 121.79 & 87.34 & & & .286 & .006 \\
\hline Active & 135 & 166.02 & 272.37 & & & & \\
\hline Total & 180 & 154.97 & 240.37 & & & & \\
\hline Innovation & & & & 5.42 & 7,45 & $.007 * *$ & .043 \\
\hline Hobby & 43 & 2.71 & .68 & & & & \\
\hline Active & 126 & 3.12 & .90 & & & & \\
\hline Total & 169 & 3.01 & .86 & & & & \\
\hline Cooperation & & & & 6.52 & 7,79 & $.006 * *$ & .045 \\
\hline Hobby & 42 & 2.52 & .89 & & & & \\
\hline Active & 126 & 2.97 & .91 & & & & \\
\hline Total & 168 & 2.86 & .93 & & & & \\
\hline Growth & & & & 8.11 & 9,45 & $.002 * *$ & .054 \\
\hline Hobby & 43 & 2.79 & 1.01 & & & & \\
\hline Active & 126 & 3.29 & .89 & & & & \\
\hline Total & 169 & 3.16 & .94 & & & & \\
\hline
\end{tabular}

\section{Logistic regression analysis}

The conceptual model and the hypotheses were tested using logistic regression analysis using SPSS version 23 . The factors separating active entrepreneurs from the non-active were further used as independent variables. In entrepreneurship studies with smaller sample sizes are common (Short, Ketchen, Combs \& Ireland, 2010). The results of the logistic regression results are displayed in Table 4. 
Table 4. Logistic regression model of variables associated with intention to develop pluriactive business activities

\begin{tabular}{|c|c|c|}
\hline \multirow[b]{2}{*}{ Independent variables } & \multicolumn{2}{|c|}{$\begin{array}{l}\text { Intention to Develop Pluriactive } \\
\text { Business Activities }\end{array}$} \\
\hline & Model $\beta$ & $\operatorname{Exp}(\beta)$ \\
\hline \multicolumn{3}{|l|}{ Personal characteristics } \\
\hline \multicolumn{3}{|l|}{ Entrepreneurs' Age } \\
\hline Entrepreneurs' Age1 & $1.562^{*}$ & 4.769 \\
\hline Entrepreneurs' Age2 & $1.632 *$ & 5.116 \\
\hline Education(1= lower level education) & .773 & 2.166 \\
\hline Gender ( $1=$ women) & 1.087 & 2.965 \\
\hline \multicolumn{3}{|l|}{ Attitude towards pluriactive business } \\
\hline Innovation & $.789 *$ & 2.200 \\
\hline Cooperation & -.133 & .876 \\
\hline Growth & .304 & 1.355 \\
\hline \multicolumn{3}{|l|}{ Farm firm's characteristics } \\
\hline Farm size & .001 & 1.001 \\
\hline Location 1 Jyväskylä urban region & .048 & 1.049 \\
\hline Production line 1 (Milk) non-primary production & $1.460^{*}$ & 4.308 \\
\hline Production line 1 (Grain) non-primary production line & -.283 & .754 \\
\hline Constant & -4.502 & .011 \\
\hline Model $\chi^{2}$ & 25.410 & \\
\hline Model significance & .008 & \\
\hline-2 log likelihood & 133.749 & \\
\hline Overall predictive accuracy & $81.1 \%$ & \\
\hline Cox and Snell $\mathrm{R}^{2}$ & .163 & \\
\hline Nagelkerke $\mathrm{R}^{2}$ & .242 & \\
\hline Number of firms & 143 & \\
\hline
\end{tabular}

${ }^{*} \mathrm{p}<.05 ; * * \mathrm{p}<.01 ; * * \mathrm{p}<.001$

Hypotheses in bold are supported. 1 =Active entrepreneurs, $0=$ Non-Active entrepreneurs.

To avoid issues of model fit that can be problematic with the use of structural equation modelling in small data sets such as this sample of pluriactive entrepreneurs and their farm firms, it is common to use logistic regression analysis. (Kline, 2005).

We want to test whether younger (under 50 years old) entrepreneurs who are not focusing on milk production as a primary production line and who have a positive attitude towards innovation, cooperation, and growth are more likely to be active pluriactive entrepreneurs. 
The significance of the individual variables was established by using the Wald $\left(\chi^{2}(1)=33,56\right)$. The overall goodness of fit of logistic regression model was evaluated using the chi-square test, the predictive accuracy of the estimated model, the Cox and Snell $r$-square coefficient and Nagelkerke $r$-square. Coefficients of the independent variables, such as production line milk, entrepreneurs' age, and innovation were entered into the model to test our hypotheses and were significant at the 0.05 level ( $95 \%$ confidence level). The overall model is a statistically significant at the .008 level according to the chisquare test $\left(\chi^{2}(1, N=189)=25.41, p<0.05\right)$. The Cox and Snell is $R^{2}=0.163$ and Nagelkerke is $R^{2}=0.242$. This means that the independent variables explain $24.2 \%$ of that probability of belonging to the category "active pluriactive entrepreneurs". The model predicts $81.1 \%$ of the responses correctly.

For the entrepreneurs 51-64 years old, the probability of being an active pluriactive entrepreneur is quadrupled $(\operatorname{Exp}(\beta)=4,7)$ compared to the under 50 years and over 65 years old entrepreneurs. The effect was positive and statistically significant at the $p<0.05$ level. Again, for the 51-64 years old and those over 65 entrepreneurs, the probability of being active pluriactive entrepreneurs will quintuple $(\operatorname{Exp}(\beta)=5,1)$ compared to entrepreneurs under 50 years. The effect was positive and significant at the 0.05 level. Age is statistically significantly and positively related to entrepreneurial intention $(\beta=0.40 ; p<0.05 ; \beta=0.025 ; p<0.50 ; \beta=0.015 ; p<0.50 ; \beta=0.050 ; p<0.50 ;)$, supporting the hypothesis (Cox and Snell $R^{2}=0.163$ ). Our analysis shows that aging increases the probability for intentions to be an active pluriactive entrepreneur. This means that aging decreases the risk of intentions to develop pluriactive business.

Respondents who did not produce milk as the main production line and who have an intention to develop pluriactive farm business were more likely to be active pluriactive entrepreneurs. The effect was positive and statistically significant at $p<0.05$. For respondents who did not produce milk as the main production line, the probability of being an active pluriactive entrepreneur quadruples $(\operatorname{Exp}(\beta)=4,31)$ compared to the milk as the main production line producers. Milk production decreases the probability of being an active pluriactive entrepreneur. This means that milk production as a primary production line decreases the risk of intention to develop pluriactive business.

Entrepreneurs who were innovation-oriented and who had the intention to develop pluriactive farm business were active pluriactive entrepreneurs. For innovation orientation, the probability of being an active pluriactive entrepreneur doubles $(\operatorname{Exp}(\beta)=2,2)$ compared to non-active entrepreneurs. The effect was positive and significant at the 0.05 level. Innovation increases the probability of intention to develop pluriactive business operations. This 
means that innovation increases the probability of intention to develop pluriactive business. Other variables seem not to be significant in this model. A replication of this study with larger samples of entrepreneurs intending to develop their pluriactive business activities may reveal a greater number of significant relationships. The results of the model indicate that the active pluriactive entrepreneurs $(n=103)$ were likely not to be milk as the main production line producers and to be innovation-oriented and slightly diversified by their age because some of them were 51-64 years old or younger (under 50 years) and only a few were over 65 years old. Our logistic regression model confirmed our hypotheses because the regression coefficients were statistically significant and in the hypothesized direction $(\beta=0.021 ; p<0.05 ; \beta=0.040 ; p<0.50 ; \beta=0.025 ; p<0.50 ; \beta=0.015 ; p<0.50 ;$ $\beta=0.050 ; p<0.50$, respectively).

\section{CONCLUSION}

The purpose of this study was to study what differentiates active and nonactive farm entrepreneurs in terms of pluriactivity and their intentions to develop their pluriactive business activities? More specifically, we wanted to examine whether the active pluriactive entrepreneurs, who have the intention to develop their pluriactive business activities, are younger, whether their educational level is higher and whether their attitudes towards pluriactivity are more innovative, cooperative and growth-oriented compared to nonactive pluriactive farm entrepreneurs.

With respect to entrepreneurs intention to develop their pluriactive farm business, active and non-active entrepreneurs showed more distinct profiles and our hypotheses were only partly supported. The active entrepreneurs' intention to develop their business activities was explained by the entrepreneurs' age, milk as production line and innovation behaviour.

Active entrepreneurs were more likely to be younger than non-active entrepreneurs, particularly in the age groups of under 50 years and 51-64 years. However, in the age group of over 65 years, non-active entrepreneurs were more likely to intend to develop their pluriactive businesses than active entrepreneurs. It seemed to us that age decreases the intention to develop pluriactive business activities, but the results are not that conclusive. Our model predicted that the probability for a small portion of older entrepreneurs to be active pluriactive entrepreneurs will grow. Our results indicate that there are diversifications within age groups between the active and non-active entrepreneurs (Carter, 1998, Carter \& Ram, 2003) and that the entrepreneurs' age is impacting the entrepreneurial process and outcomes related to firm development (Shane, 2003). Milk producers were not likely 
to be active pluriactive entrepreneurs, and they did not have the intention to develop pluriactive farm business activities. As regards the pluriactivity, it can be expected that different types of farm business activities have impact on intention to develop pluriactive business just as different business sectors do. We also found that active entrepreneurs were more likely to be innovative than non-active entrepreneurs. The results of this explorative study may not generalize across the regions, countries or cultures. Another limitation is the low explanatory power of the regression model. Our sample of 189 pluriactive farm firms may be too homogenous to make distinctions within the group of pluriactive entrepreneurs.

This study establishes that intentions for active and non-active pluriactive entrepreneurs are different. The constructs associated within and between pluriactivity vary and that attitudes towards pluriactivity such as innovation, cooperation and growth have a differential effect on entrepreneurial intentions as determinants (or not) of the type of pluriactive business (whether active or non-active pluriactive business activities). The innovation attitude appears to be related only to the intention to develop pluriactive business activities, whereas cooperation and growth attitudes, which are generally supposed to be strong drivers of development and growth (Bird \& Jelenik, 1988; Granovetter, 1973; Markatoni et al., 2013; Ozcan \& Eisenhardt, 2009) were more likely to be non-significant with respect to intention to develop pluriactive business.

\section{Acknowledgment}

The author gratefully acknowledges the support and generosity of Yksityisyrittäjäin Säätiö.

\section{References}

Ajzen, I. (1991). The theory of planned behavior. Organization Behavior and Human Decision Processes, 50(2), 179-211.

Ajzen, I. (2011). Theory of planned behavior. Psychology and Health, 26(9), 1113-1127.

Ajzen, I., Fishbein, M. (1980). Understanding attitudes and predicting social behavior. Englewood Cliffs, NJ: Prentice-Hall.

Alsos, G. A., Carter, S., Ljunggren, E., Welter, F. (2011). The handbook of research on entrepreneurship in agriculture and rural development. Northampton, MA: Edward Elgar.

Atterton, J., Affleck, A. (2010). Rural businesses in the North East of England: final survey results. Newcastle: Newcastle University, Centre for Rural Economy. 
Bagozzi, R. P., Baumgartner, J., Yi, Y. (1989). An investigation into role of intentions as mediators of the attitude -behavior relationship. Journal of Economic Psychology, 10(1), 35-62.

Bandura, A. (1977). Social learning theory. Englewood Cliffs, NJ: Prentice Hall. Barkham, R. J. (1994). Entrepreneurial characteristics and the size of the new firm: a model and econometric test. Small Business Economics 6(2), 117125.

Barney, J. (1991). Firm resources and sustained competitive advantage. Journal of Management, 17(1), 99-120.

Bellu, R.R., Sherman, H. (1995). Predicting business success from task motivation and attributional style: a longitudinal study. Entrepreneurship and Regional Development, 7(4), 349-363.

Bird, B. (1988). Implementing entrepreneurial ideas. The case of intention. Academy of Management Review, 13(3), 442-453.

Bird, B. (1992). The operation of intentions in time: The emergence of the new venture. Entrepreneurship Theory and Practice, 17(1), 11-27.

Bird, B., Jelinek, M. (1988). The operation of entrepreneurial intentions. Entrepreneurship Theory and Practice, 13(2), 21-29.

Bowler, I., Clark, G., Crockett, A., Ilbery, B., Shaw, A. (1996). The development of alternative farm enterprises: a study of family labour farms in the Northern Pennines of England. Journal of Rural Studies, 12(3), 285-95.

Borges, J. A. R.; Foletto, L., Vanderson, T. X. (2015). An interdisciplinary framework to study farmers' decisions on adoption of innovation: Insights from expected utility theory and theory of planned behavior. African Journal of Agricultural Research, 10(29), 2814-2825.

Busenitz, L. M., West, G. P., Shepherd, D., Nelson, T., Chandler, G. N., Zacharakis, A. (2003). Entrepreneurship research in emergence: Past trends and future directions. Journal of Management, 29(3), 285-308.

Carter S., Ram, M. (2003). Reassessing portfolio entrepreneurship. Small Business Economics, 21(4), 371-380.

Carter, S. (1998). Portfolio entrepreneurship in the farm sector: Indigenous growth in rural areas? Entrepreneurship and Regional Development, 10(1), 17-32.

Chang, S-J., van Witteloostuijn, A., Eden L. (2010). From editors: Common method variance in international business research. Journal of International Business Studies, 41(2), 178-184.

Davidsson, P., Honig, B. (2003). The role of social and human capital among nascent entrepreneurs. Journal of Business Venturing, 18(3), 301-331.

Davidsson, P., Wiklund, J. (2001). Levels of analysis in entrepreneurship research. current research practice and suggestions for the future. Entrepreneurship theory and practice, 25(4), 81-100.

De Silva, L. R., Kodithuwakku, S.S. (2011). Pluriactivity, entrepreneurship and socio-economic success of farming households. In: G. A. Alsos, S. Carter, E. L. Ljunggren, F. Welter (Eds.), The Handbook of Research on 
Entrepreneurship in Agriculture and Rural Development (pp. 38-53). Northampton, MA: Edward Elgar.

Douglas, E. J. (2013). Reconstructing entrepreneurial intentions to identify predisposition for growth. Journal of Business Venturing, 28(5), 633-651.

Douglas, E. J., Shepherd, D. (2002). Self-employment as career choice: attitudes, entrepreneurial intentions and utility maximization. Entrepreneurship Theory and Practice, 26(3), 81-90.

Evans, N., Ilbery, B. (1993). The pluriactivity, part-time farming and farm diversification debate. Environment and Planning, A 25, 945-959.

Gibb, A. (2000). Corporate restructuring and entrepreneurship: What can large organizations learn from small? Enterprise \& Innovation Management Studies, 1(1), 19-35.

Grande, J. (2011a). Entrepreneurial efforts and change in rural firms: three case studies of farms engaged in on-farm diversification. In: G.A. Alsos, S. Carter, E.L. Ljunggren, F. Welter (Eds.), The Handbook of Research on Entrepreneurship in Agriculture and Rural Development (pp.74-93). MA: Northampton, Edward Elgar Publishing.

Grande, J. (2011b). New venture creation in the farm sector - Critical resources and capabilities, Journal of Rural Studies, 27(2), 220-233.

Grande, J., Madsen, E. L., Borch, O. J. (2011). The relationship between resources, entrepreneurial orientation and performance in farm-based ventures. Entrepreneurship and Regional Development, 23(3-4), 89-111.

Granovetter, M. (1973). The strength of weak ties. American Journal of Sociology, 78(6), 1360-1380.

Haugen, M. S., Vik. J. (2008). Farmers as entrepreneurs: the case of farmbased tourism. International Journal of Entrepreneurship and Small Business, 6(3), 321-336.

Hill, B. (2000). Farm incomes, wealth and agricultural policy. Aldershot: Ashgate Publishing.

Kinsella, J., Wilson, S., De Jong, F., Renting, H. (2000). Pluriactivity as a livelihood strategy in Irish farm households and its role in rural development. Sociologia Ruralis, 40(4), 481-496.

Kline, R. B. (2005). Principles and practice of structural equation modelling. New York: Guilford.

Kolvereid, L. (1996). Prediction of employment status choice intentions. Entrepreneurship Theory and Practice, 20(3), 47-57.

Kolvereid, L. E., Bullvåg, E. (1996). Growth intentions and actual growth: the impact of entrepreneurial choice. Journal of Enterprising Culture, 4(1), 1-17.

Krueger, N. F. (1993). The impact of prior entrepreneurial exposure on perceptions of new venture feasibility and desirability. Entrepreneurship Theory and Practice, 18(1), 5-21.

Krueger, N., Carsrud, A. (1993). Entrepreneurial intentions: Applying the theory of planned behavior. Entrepreneurship and Regional Development, 5(4), 315-330. 
Krueger, N. F., Brazeal, D. V. (1994). Entrepreneurial potential and potential entrepreneurs. Entrepreneurship Theory and Practice, 18(3), 91-104.

Krueger, N., Reilly, M., Carsrud, A. (2000). Competing models of entrepreneurial intentions. Journal of Business Venturing, 15(5-6), 411-432.

Lechner, C., Dowling, M., Welpe, I. (2006). Firm networks and firm development. The role of the relational mix. Journal of Business Venturing, 21(4), 514-540.

Linan, F., Chen, Y. W. (2009). Development and cross -cultural application of a specific instrument to measure entrepreneurial intentions. Entrepreneurship Theory and Practice, 33(3), 593-617.

Lumpkin, G. T., Dess, G. G. (2005). Entrepreneurial orientation. In: G. T. Lumpkin, G. G. Dess (Eds.), Wiley Encyclopedia of Management. Volume 3. Entrepreneurship (pp. 1-4). Hoboken, NJ: John Wiley and Sons.

Lynne, G. D., Casey, C. F., Hodges, A., Rahmani, M. (1995). Conservation technology adoption decisions and the theory of planned theory. Journal of Economic Psychology, 16(4), 581-598.

Markantoni, M., Strijker, D., Koster, S. (2013). Growth expectations for side activities on rural areas. Journal of Small Business and Enterprise Development, 20(1), 584-602.

McGee, J. E., Peterson, M., Mueller, S. L., Sequeira, J. M. (2009). Entrepreneurial self-efficacy. Refining the measure. Entrepreneurship Theory and Practice, 33(4), 965-988.

McNally, S. (2001). Farm diversification in England and Wales. What can we learn from the farm business survey? Journal of Rural Studies, 17(21), 247-257.

Minniti, M., Bygrave, W. (2001). A dynamic model of entrepreneurial learning. Entrepreneurship Theory and Practice, 25(3), 5-16.

Niemelä, T. (2004). Inter-firm cooperation capability in the context of networking family firms: The role of power. Family Business Review, 17(4), 319- 330.

Niemelä. T., Häkkinen, R. (2014). The role of pluriactivity for continuity and survival in family farm firms. Journal of Entrepreneurship, Management and Innovation, 10(4), 7-43.

Niemelä, T., Heikkilä, E., Meriläinen, T. (2005). Monialainen yritystoiminta Keski-Suomen maatiloilla. Jyväskylä: Jyväskylän yliopisto, taloustieteiden tiedekunta. Julkaisuja N:o 148.

North, D., Smallbone, D. (1996). Small business development in remote rural areas. The example of mature manufacturing firms in northern England. Journal of Rural Studies, 12(2), 151-167.

Nunnally, J. (1978). Psychometric theory. New York: McGraw-Hill.

Orser, B., Hogarth-Scott, S., Wright, P. (1998). On the growth of small enterprises: The role of intentions, gender and experience. In: $P$. Reynolds, W. Bygrave, S. Carter, C. M. Manigart, C. M. Mason, G. D. Meyer, K. G. Shaver (Eds.), Frontiers of Entrepreneurship Research (pp. 366-380). Wellesley, MA: Babson College. 
Ozcan, P., Eisenhardt, E.M. (2009). Origin of alliance portfolios: entrepreneurs, network strategies and firm performance. Academy of Management Journal, 52(2), 246-279.

Politis, D. (2005). The process of entrepreneurial learning: A conceptual framework. Entrepreneurship Theory and Practice, 29(4), 399-424.

Rantamäki-Lahtinen, L. (2009). The success of the diversified farm : resource-based view (Ph.D dissertation). Retrieved from http://urn.fi/ URN:ISBN:978-952-487-228-7.

Rosa, P., Carter, S., Hamilton, D. (1996). Gender as a determinant of small business performance insights from a British study. Small Business Economic, 8(6), 463-478.

Rotefoss, B., Kolvereid, L. (2005). Aspiring, nascent and fledgling entrepreneurs: An investigation of the business start-up process. Entrepreneurship \& Regional Development, 17 (2), 109-127.

Schjoedt, L., Shaver, K. G. (2004). Does the potential for increased work and life satisfaction affect the decision to pursue an entrepreneurial career? An examination of the PSED data. First Annual Clemson/Kauffman Symposium on the PSED. Clemson, South Carolina.

Shane, S. (2003). A general theory of entrepreneurship. Cheltenham: Edward Elgar.

Shane, S. (2009). Why encouraging more people to come entrepreneurs is bad public policy. Small Business Economics, 33(2), 141-149.

Shapero, A., Sokol, L. (1982). The social dimensions of entrepreneurship. In: C. A. Kent, D. L. Sexton, K. H. Vesper (Eds.), Encyclopedia of entrepreneurship (pp. 72-98). Englewood Cliffs, NJ: Prentice Hall.

Short, J. C., Ketchen, D. J. J., Combs, J. G., Ireland, R. D. (2010). Research methods in entrepreneurship. Organizational Research Methods, 13(1), 6-15.

Sullivan, R. (2000). Entrepreneurial learning and mentoring. International Journal of Entrepreneurial Behavior \& Research, 6(3), 160-175.

Storey, D. J. (1994). Understanding the small business sector. London: Routledge.

Ucbasaran, D., Westhead, P., Wright, M. (2009). The extent and nature of opportunity identification by repeat entrepreneurs. Journal of Business Venturing, 24(2), 99-115.

Webb, T. L., Sheeran, P. (2006). Does changing behavioral intentions engender behavior change? A meta-analysis of the experimental evidence. Psychological Bulletin, 132(2), 249-268.

Wernerfelt, B. (1984). A resource-based view of the firm. Strategic Management Journal, 5(2), 171-80.

Wiklund, J., Shepherd, D. (2005). Entrepreneurial orientation and small business performance: A configurational approach. Journal of Business Venturing, 20(1), 71-91. 
Wiklund, J., Shepherd, D. (2003). Aspiring for, and achieving growth: The moderating role of resources and opportunities. Journal of Management Studies, 40(8), 1919-1941.

Zhou, K. Z., Yim, C. K., Tse, D. K. (2005). The effects of strategic orientations on technology- and market-based breakthrough innovations. Journal of Marketing, 69(2), 42-60.

\section{Biographical note}

Tarja Niemelä, Ph.D, is an adjunct professor at the School of Business and Economics; University of Jyväskylä. Her main research area encompasses the issues of networking and cooperation, growth of the firm, venture creation, entrepreneurial intentions and learning in organizations. Her research interests are focused on entrepreneurship in rural areas and family entrepreneurship. She is an experienced educator and trainer in business school and other business organizations.

\section{Abstrakt (in Polish)}

Praca wnosi wkład w badania nad intencjami przedsiębiorczymi poprzez zastosowanie teorii planowanego zachowania i podejścia zasobowego w odniesieniu do modelu przedsiębiorców zamierzajq̨cych rozwijać gospodarstwa rolne o zróżnicowanych profilach działalności (ang. pluriactivity). Korzystajqc z danych sondażowych zebranych w 2012 roku w firmach rolniczych w Finlandii, koncentrujemy się na aktywnych przedsiębiorcach rolnych $i$ ich intencjach dotyczqcych rozwijania działalności o profilu odmiennym od rolnego. Badania wykazały zróżnicowany wpływ na wieloprofilowa dziatalność przedsiębiorców aktywnych i nieaktywnych zmiennych takich jak innowacyjność, współpraca, rozwój, jak również różnic w zakresie wieku przedsiębiorcy, profilu gospodarczego firmy oraz zachowań pro-innowacyjnych.

Słowa kluczowe: intencje przedsiębiorcze, działalność gospodarcza niezwiqzana z rolnictwem, przedsiębiorcy prowadzacy gospodarstwa wieloprofilowe, teoria planowanego zachowania, podejście zasobowe

\section{Appendix}

A. Descriptive statistics of the explanatory variables and measurement scale items (with $\mathrm{p}$-values for the full Sample ( $\mathrm{N}=448$, all farms) and for the pluriactive sample $(\mathrm{N}=189)$

\begin{tabular}{lllll}
\hline Variables & Scale & Items & $\begin{array}{l}\text { All farms } \\
\text { p-value }\end{array}$ & $\begin{array}{l}\text { Pluriactive } \\
\text { p-value }\end{array}$ \\
\hline Location & 1,2 & $\begin{array}{l}\text { The location of the farms: } 1= \\
\text { Jyväskylä region, }(n=97) 2=\text { other } \\
\text { areas in Central Finland }(n=351), \\
\\
N=448\end{array}$ & $.036^{*}$ & .443 \\
& & &
\end{tabular}




\begin{tabular}{|c|c|c|c|c|}
\hline $\begin{array}{l}\text { Sum Farm } \\
\text { Size }\end{array}$ & Continuous & $\begin{array}{l}\text { Sum variable including the area of } \\
\text { cultivated fields and forest (ha): } \\
0-10,11-30,31-60,61-120,101- \\
180,181-300,301-(N=438)\end{array}$ & $\begin{array}{l}\text { only mean } \\
\text { value } \\
\text { reported }\end{array}$ & $\begin{array}{l}\text { only mean } \\
\text { value } \\
\text { reported }\end{array}$ \\
\hline $\begin{array}{l}\text { Production } \\
\text { Line }\end{array}$ & 1,2 & $\begin{array}{l}\text { Production line: } 1 \text { = grain, }(n=444) \\
2=\text { milk, }(n=444) \\
(1=\text { primary production line }, 2) \\
\text { secondary production line })\end{array}$ & $\begin{array}{l}.429 \\
.052^{*}\end{array}$ & $\begin{array}{l}.229 \text { (Grain) } \\
.038^{* *} \text { (Milk) }\end{array}$ \\
\hline $\begin{array}{l}\text { Entrepre- } \\
\text { neur's Age }\end{array}$ & continuous & $\begin{array}{l}\text { The age of the respondent in years: } \\
1=\text { under } 50(n=144), 2=51-64 \\
(n=199), 3=\text { over } 65 \text { years }(n=105) \\
N=448\end{array}$ & $.000 * * *$ & $.001 * * *$ \\
\hline $\begin{array}{l}\text { Sum Educa- } \\
\text { tion }\end{array}$ & 1,2 & $\begin{array}{l}\text { Sum variable including the basic } \\
\text { education of the respondent and } \\
\text { the spouse (high school = } 1 \text {, other } \\
=0 \text { ) and vocational education and } \\
\text { training ( } 1=\text { post-secondary level, } \\
\text { polytechnic or university, } 0=\text { other) } \\
(\mathrm{N}=458) \text {. }\end{array}$ & $.003 * *$ & .658 \\
\hline Gender & 1,2 & $\begin{array}{l}1=\text { female }(n=92), 2 \text { =male }(n=354) \\
N=446\end{array}$ & $.009 * *$ & .813 \\
\hline Innovation & continuous & $\begin{array}{l}\text { Statements regarding respondents } \\
\text { relationship to pluriactive business: } \\
\text { 1) In our field of industry other } \\
\text { entrepreneurs often seek to learn } \\
\text { in their own operations from us } \\
\text { ( } n=169 \text { ) } \\
\text { 2) We constantly seek new ideas } \\
\text { and opportunities to develop our } \\
\text { business ( } n=169 \text { ) } \\
\text { 3) We have often noticed to be } \\
\text { the first experimenter in our field } \\
\text { (n=169) }\end{array}$ & not surveyed & $.000 * * *$ \\
\hline Cooperation & continuous & $\begin{array}{l}\text { Statements regarding respondents } \\
\text { relationship to pluriactive business } \\
\text { 1) We are often the initiator of the } \\
\text { cooperation and networking ( } n=168) \\
\text { 2) We are actively seeking more } \\
\text { cooperation partners ( } n=168) \\
\text { 3) We are constantly seeking more } \\
\text { and more cooperation possibilities } \\
\text { with our existing co-partner }(n=168)\end{array}$ & not surveyed & $.012 * *$ \\
\hline Growth & continuous & $\begin{array}{l}\text { Statements regarding respondents } \\
\text { relationship to pluriactive business } \\
\text { 1) We consider growth as the pivotal } \\
\text { target in our business ( } n=169) \\
\text { 2) Growth and profitability go hand } \\
\text { in hand }(n=169)\end{array}$ & not surveyed & .338 \\
\hline
\end{tabular}

$\mathrm{p}<.001^{* * *} ; \mathrm{p}<.01 * * \mathrm{p}<.05^{*}$ statistical significance. Note: innovation, cooperation and growth variables were not surveyed/measured concerning traditional farms, i.e., those who did not have pluriactive business activities. 
